DOI: $10.2478 / \mathrm{v} 10047-011-0006-9$

\title{
ELECTRIC CONDUCTIVITY OF Sb/Se THIN FILM MICRO-SCALE STRUCTURES
}

\author{
O. Shiman, V. Gerbreder, E. Sledevsky, A. Bulanov \\ Innovative Microscopy Center, Daugavpils University, \\ 1 Parades Str., Daugavpils, LV-5400, LATVIA \\ e-mail: osimane@gmail.com
}

\begin{abstract}
Research into the phase change transition (PCT) from amorphous to crystalline state in chalcogenide glass semiconductors is often more associated with large-scale samples. The authors present a micro-scale structural model of the $\mathrm{Sb} / \mathrm{Se}$ thin films. They have also extended the investigations of photo- and thermostimulated inter-diffusion and PCT effects between two adjacent layers. The results show that the optical and electrical characteristics of such a film change simultaneously. It has been found that the electric conductivity of the films increases 3 times during a PCT process.
\end{abstract}

\section{INTRODUCTION}

$\mathrm{Se}-\mathrm{Sb}$ glasses have been proved to be attractive candidates in optical and electronic communications, switching \& memory devices, and photovoltaic applications [1-6]. Apart from that, a Se-Sb glassy system can be considered consisting of the basic a-Se network with Sb added as impurity. The addition of antimony to chalcogenide glasses is generally accompanied by a marked change in their electrical and photoelectrical properties. To this issue a series of works are devoted [7-11].

The application of Sb-containing glasses has generally been limited because of their strong tendency for crystallization, especially when the Sb content is substantial. The effect of Sb alloying on the electrographic properties of a-Se and laser-induced amorphous-to-crystalline phase transition in glassy $\mathrm{Se}-\mathrm{Sb}$ alloys is reported by Mikla [12-13]. The $\mathrm{Se}-\mathrm{Sb}$ system was also widely studied as a suitable medium both for erasable and WORM applications (Tokushuku et al. [14]).

Modern studies in the PRAM (phase change random access memory) field are focused on the chalcogenide materials used for rewritable optical recording disks [15-17]. In this field, the GST (GeSbTe, Germanium-Antimony-Tellurium) material is widely used; however, owing to its high melting temperature and low resistivity a high reset current $(>1 \mathrm{~mA})$ is needed, which leads to increased power consumption of the memory device. To reduce it, some attempts have been made (see, e.g. [18-20]). In our experiments, we investigated $\mathrm{Sb}-\mathrm{Se}$ bilayer structures as phase change materials with a lower melting temperature than that of GST.

A number of research works have been done with $\mathrm{Sb}-\mathrm{Se}$ alloys to investigate these materials for application in rewritable optical disks [21-23]. However, little attention was paid to the photo-electrical properties of these glasses in micro- and nano-scale structures. 
In the present work, we report the experimental results of research into the electric conductivity of $\mathrm{Sb}-\mathrm{Se}$ bilayered micro-scale structures $(10 \times 30 \mu \mathrm{m})$ prepared by the conventional thermal evaporation technique. The structural characteristics were changed by laser irradiation and direct current.

\section{EXPERIMENTAL}

A Sb-Se bilayered thin film was prepared by thermal evaporation from highpurity $\mathrm{Sb}$ and $\mathrm{Se}$, in the vacuum of 10-5 Torr onto BK-7 glass substrates at room temperature (RT). In the formation of micro-scale structures, photolithographic techniques were used to illuminate and then to pattern the photoresist. In this manner, rectangular bilayered structures $(10 \times 30 \mu \mathrm{m}$ bridges $)$ with lead electrodes were produced (Fig. 1).

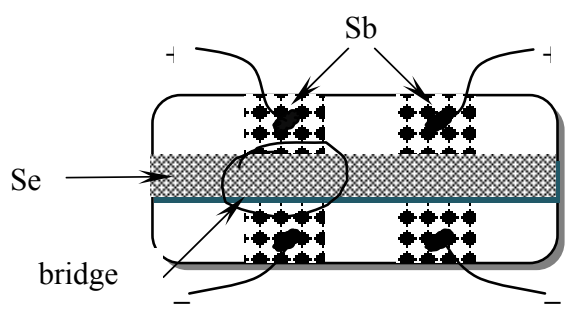

Fig. 1. Sb/Se bilayered micro-scale structures.

During the evaporation, the film thickness was controlled applying the interference technique at a wavelength of $890 \mathrm{~nm}$ (as shown in [24]). In the experiments, $100 \mathrm{~nm}$ thick Se films were used. The thickness of metal layers on the selenium surface was $\sim 300 \mathrm{~nm}$. The composition and structure of the deposed layers were analyzed using an INCA X-act detector and an X-ray diffractometer (SmartLab Rigaku).

To study the light-induced inter-diffusion, we irradiated the sample at RT by a He-Ne laser $(\lambda=633 \mathrm{~nm})$ with the intensity of $15 \mathrm{~mW}$. The Sb-Se bilayered thin film was irradiated both on the $\mathrm{Sb}$ and Se surfaces. It was found that the lightinduced changes in such a film occured at a faster rate when it was irradiated from the Se side.

The electrical conductivity measurements were carried out using a conventional circuit with a digital DVF 1100 multielectrometer and a Tekstronix Digital Phosphor Oscilloscope TDS3054B. For the contacts silver paste was taken.

A confocal laser-scanning microscope (Leica TCS-SPECIFIC) and a scanning electron microscope (TESCAN VEGA) were employed to study the surface modifications induced by the light or heat treatment of the $\mathrm{Sb} / \mathrm{Se}$ bilayered thin films.

\section{RESULTS}

Figure $2 a$ (the as-deposed films) clearly shows several $\mathrm{Sb}$ crystalline peaks that appear in the amorphous background. 
a)

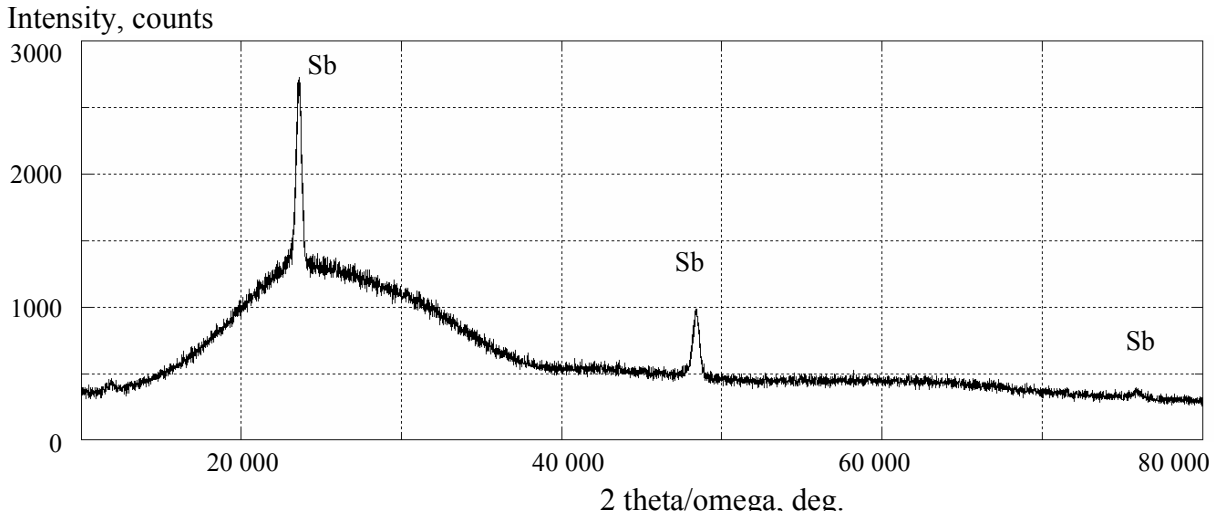

b) Intensity counts

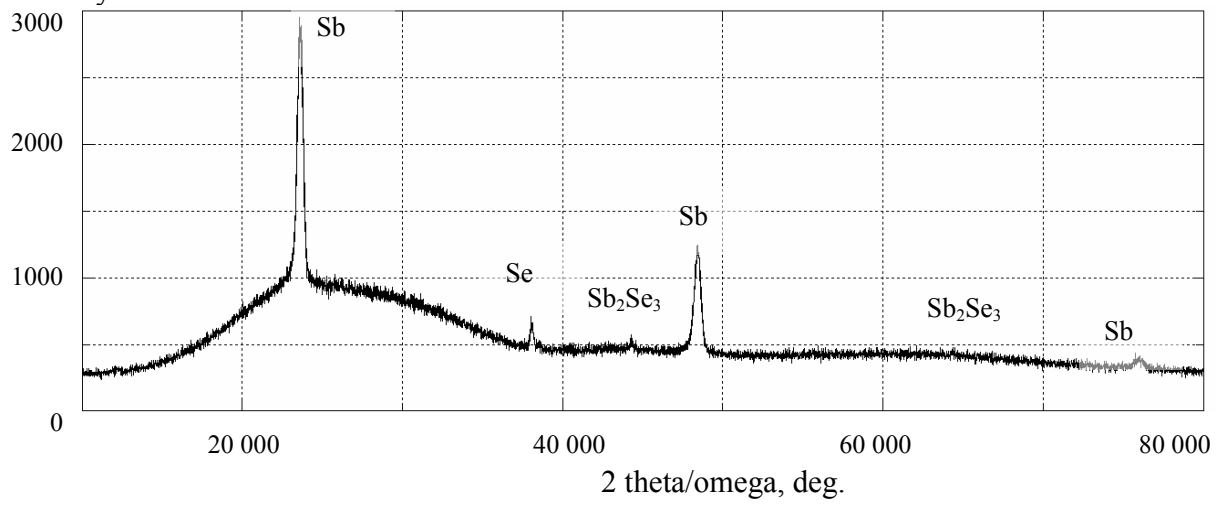

Fig. 2. X-ray diffraction picture of Sb-Se films: as-deposed $(a)$; after laser illumination $(b)$.

Light stimulation $(\lambda=633 \mathrm{~nm})$ of the $\mathrm{Sb}-\mathrm{Se}$ system is found to change its optical parameters because of inter-diffusion between $\mathrm{Sb}$ and $\mathrm{Se}$ and further crystallization. At the beginning of illumination, the crystallization process cannot develop owing to the fast inter-diffusion which creates a solid solution resistant to crystallization. The process of bleaching (A-band in Fig. $3 a$ ) transforms to that of darkening (B-band) caused by crystallization. The photo-bleaching in $\mathrm{Sb} / \mathrm{Se}$ samples is most likely associated with the light-stimulated inter-diffusion, i.e., antimony diffuses in selenium, so the optical transmission $(\mathrm{T})$ of the structure increases while its reflection (R) decreases. The photo-darkening is caused by appearance of small crystallites in the amorphous matrix, which also causes an increase in the reflection and a decrease in the transmission. Figure $2 b$ confirms the crystalline substance growth in the $\mathrm{Sb}-\mathrm{Se}$ sample: the $\mathrm{Sb}$ crystalline peaks are much higher than those in Fig. $2 a$; the $\mathrm{Se}$ and $\mathrm{Sb}_{2} \mathrm{Se}_{3}$ peaks appear, whereas the amorphous background level of the $\mathrm{Sb}-\mathrm{Se}$ sample steadily decreases.

Figure 4 shows the images of surface evolution in the $\mathrm{Sb}$-Se sample under irradiation. In Fig. $4 a$, a chaotic mix of light and dark spots on the as-deposed film surface is seen. After the light stimulation, $50-100 \mathrm{~nm}$ clusters appear on the sample (Fig. $4 b$ ). The cluster is composed of crystallized $\mathrm{Sb}$, Se and $\mathrm{Sb}_{2} \mathrm{Se}_{3}$.

The electrical properties of $\mathrm{Sb}-\mathrm{Se}$ were studied on rectangular $10 \times 30 \mu \mathrm{m}$ bridges with lead electrodes to the Sb layer. 
a)

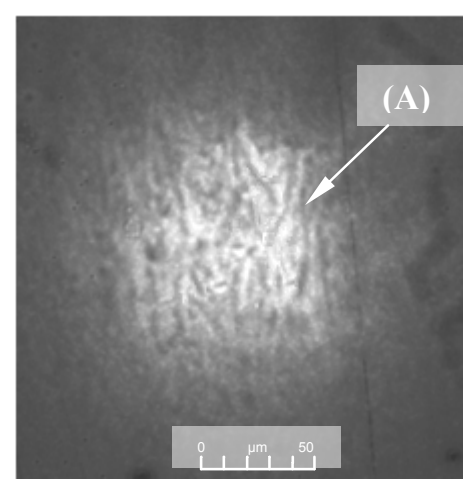

b)

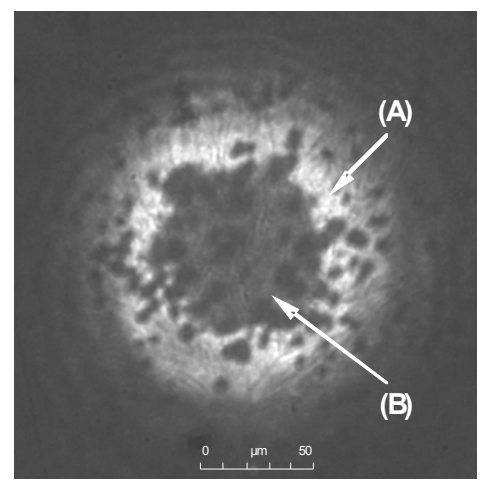

Fig. 3. Sb/Se bilayered film surface after $10 \mathrm{~min}(a)$ and $30 \min (b)$ laser stimulation $(\lambda=633 \mathrm{~nm})$. Transmitted light image: (A) - interdiffusion band, (B) - crystallization band.

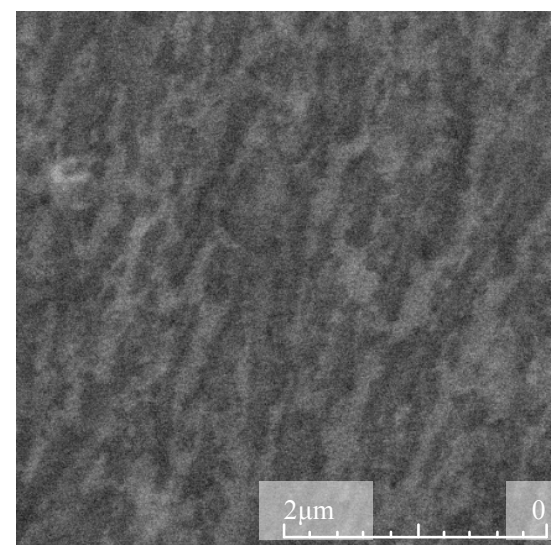

a)

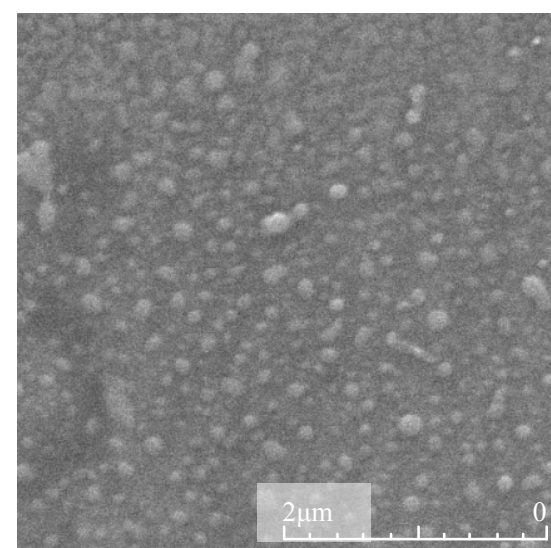

b)

Fig. 4. SEM- image of Sb-Se sample surface:

(a) - as-deposed sample; $(b)$ - sample after irradiation.

The volt-ampere characteristic of such a bridge obtained in simple nondestructive measurements is linear, which means that direct current flows through the $\mathrm{Sb}$ layer surface. When electric potential difference is applied across the film, irradiation of the bridge sharply reduces the electrical conductivity of the sample (from $10^{2.5}$ to $10^{1} \mathrm{Ohm} / \mathrm{cm}$, see Fig. 5), which is followed by a $38 \%$ reduction in reflectance (from $45 \%$ to $7 \%$ ). This can be explained by the inter-diffusion process between $\mathrm{Sb}$ and $\mathrm{Se}$.

The system's reflectance decreases up to point A (Fig. 5, curve 2). After that, the process of system crystallization is accompanied with a slight increase in the reflectance. If we assume that there is a disordered system at point $\mathrm{A}$ and an ordered system at point $\mathrm{B}$, this would mean that the system's crystallization enhances the electrical conductivity 3 times. A reverse transfer of the bridge in the disordered state can be realized with short light or current pulse. As we suppose, improvement of the lead electrodes would allow increase in the conductivity by the factor of ten.

The direct current flowing through the bridge in the crystalline state causes the initial increase in the electrical conductivity from 11.4 to $11.8 \mathrm{Ohm} \cdot \mathrm{cm}^{-1}$, with further saturation of the process (Fig. 6). 


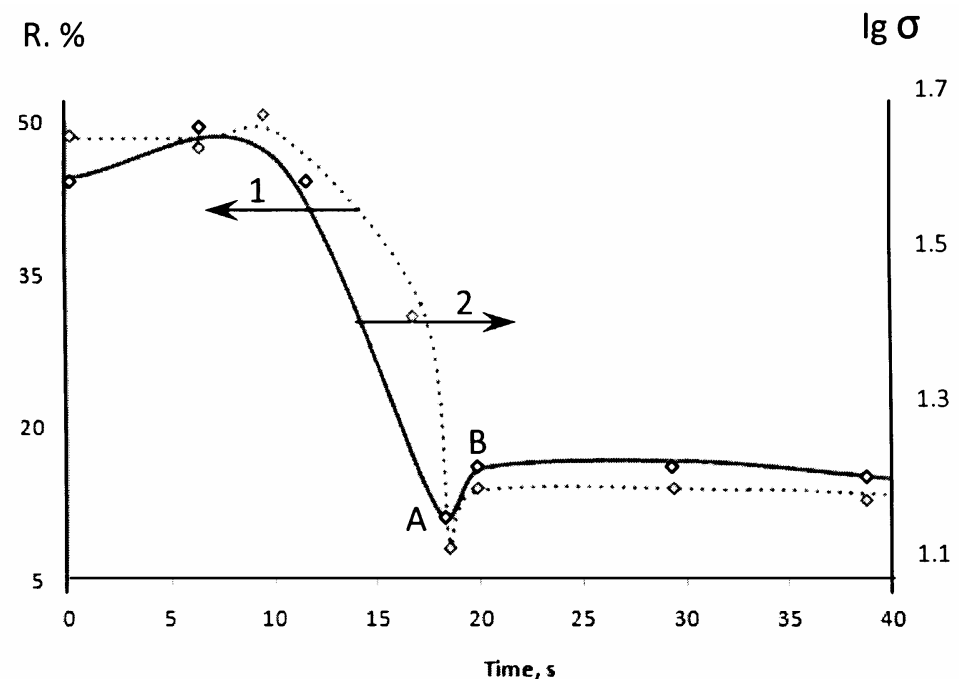

Fig. 5. Time dependences of reflectivity and electrical conductivity for a $\mathrm{Sb}-\mathrm{Se}$ bilayered film $(\lambda=633 \mathrm{~nm}, \mathrm{U}=0.5 \mathrm{~V})$.

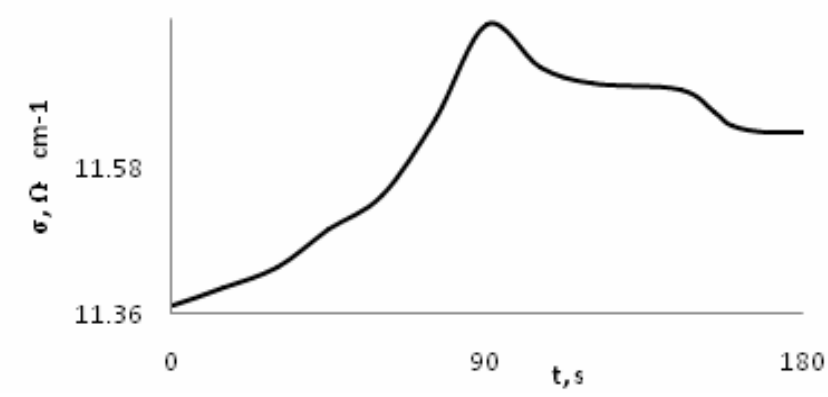

Fig. 6. Time dependence of the electrical conductivity for a Sb-Se bilayered film.

\section{CONCLUSIONS}

1. Sb-Se bilayer micro-scale structures $(10 \times 30 \mu \mathrm{m})$ have been obtained in which light-stimulated $\mathrm{Sb}$ and $\mathrm{Se}$ inter-diffusion with further crystallization occur.

2. Transition of disordered microstructures to the ordered state results in a threefold increase in the electrical conductivity.

\section{ACKNOWLEDGEMENT}

The work was supported by ESF (project „, Support for doctoral studies at the Daugavpils University, Nr. 2009/0140/1DP/1.1.2.1.2/09/IPIA/VIAA/015).

\section{REFERENCES}

1. Rowlands, J., \& Kasap, S. (1997). Amorphous semiconductors usher in digital X-ray imaging. Physics Today, 50 (11), 24-30.

2. Strand, D.J. (2005). Ovonics: from science to products. J. Optoelectronics and Advanced Materials, 7 (4), 1679-1690.

3. Stronski, A.V., \& Vlcek, M. (2002). Imaging properties of $\mathrm{As}_{40} \mathrm{~S}_{40} \mathrm{Se}_{20}$ layers. J. Optoelectronics and Advanced Materials, 4 (3), 699-704. 
4. Aggarwal, I.D., \& Sanghera, J.S. (2002). Development and applications of chalcogenide glass optical fibers at NRL. J. Optoelectronics and Advanced Materials, 4 (3), 665-678.

5. Andriesh, A.M., Iovu, M.S., \& Shutov, S.D. (2002). Competitive photostructural effects in Ge-Se glass. J. Optoelectronics and Advanced Materials, 4 (3), 631-647.

6. Ohta, T. (2001). Phase-change optical memory promotes the DVD optical disk. $J$. Optoelectronics and Advanced Materials, 3 (3), 609-626.

7. Sakata, H., \& Nakao, N. (1993). Electrical conductivity of amorphous chalcogenide films in As-Se-Sb system. J. Non-Crystalline Solids, 163, 236-241.

8. Giridhar, A., \& Mahadevan, S. (1992). Floppy to rigid transition and chemical ordering in Ge-Sb(As)-Se glasses. J. Non-Crystalline Solids, 143, 52-58.

9. Fadel, M. (1999). The effect of the Sb content on the physical properties of amorphous $\mathrm{Se}_{0.75} \mathrm{Ge}_{0.25-y}$ thin films. Vacuum, 52 (3), 277-284.

10. Mehra, R.M., Kaur G., \& Mathur, P.C. (1993). Effect of antimony impurity on photoconduction in thin films of Se-Te system. Solid State Communications, 85 (1), 29-31.

11. Mathew, G., \& Philip, J. (1999). Characteristics of photoconductivity in As-Sb-Se glasses. PRAMANA- J. Phys., 53 (5), 891-902.

12. Mikla, V.I., Nagy, Yu., Mikla, V.V., \& Mateleshko, A.V. (1999). The effect of Sb alloying on the electrophotographic properties of amorphous selenium. Materials Sci. and Eng-g, B, 64 (1), 1-5.

13. Mikla, V.I., Mikhalko, I.P., \& Mikla, V.V. (2001). Laser-induced amorphous-tocrystalline phase transition in $\mathrm{Sb}_{\mathrm{x}} \mathrm{Se}_{1-\mathrm{x}}$ alloys. Materials Sci. and Eng-g, B, 83 (1-3), 74-78.

14. Tokushuku, N., Moritani, K., Yanagihara, H., Konishi, K., \& Noro, Y. (1992). High $\mathrm{C} / \mathrm{N}$ recording in $\mathrm{Sb}_{2} \mathrm{Se}_{3} / \mathrm{Bi}$ write-once disk. Jpn. J. Appl. Phys., 31 (2S), 456-460.

15. Popescu, M.A. (2002). Physics and Applications of Disordered Materials. Bucharest: INOE Publishing House.

16. Rowlands, J., \& Kasap, S. (1997). Amorphous semiconductors usher in digital X-ray imaging. Physics Today, 50 (11), 24-30.

17. Oosthoeka, J., Kooi, B.J., Hosson, J.D., Gravesteijn, D., Attenborough, K., Wolters, R., \& Verheijen, M. (2009). Crystallization studies of doped SbTe phase-change thin films and PRAM line cells: growth rate determination by automated TEM image analysis. In: European Symp. on Phase Change and Ovonic Sci., 5-7 September, 99-104. Aachen (Germany): Aachen University.

18. Lai, S., \& Lowrey, T. (2001). OUM-A $180 \mathrm{~nm}$ nonvolatile memory cell element technology for stand alone and embedded applications. IEMD Tech. Dig., 803-806.

19. Hosaka, S., Miyauchi, K., Tamura, T., Sone, H., \& Koyanagi, H. (2004). Proposal for a memory transistor using phase-change and nanosize effects. Microelectronic Engineering, 73-74 (1), 736-740.

20. Lai, S. (2003) Current status of the phase change memory and its future. IEDM Tech. Dig., 255-258.

21. Barton, R., Davis, C.R., Rubin, K., \& Lim, G. (1986). New phase-change material for optical recording with short erase time. Appl. Phys. Lett., 48, 1255-1257.

22. Dimitrov, D., Tzocheva, D., \& Kovacheva, D. (1998). Calorimetric study of amorphous Sb-Se thin films. Thin Solid Films, 323 (1-2), 79-84.

23. Babeva, T., Dimitrov, D., Kitova, S., \& Konstantinov, I. (2000). Optical properties of phase-change optical disks with SbxSe100-x films. Vacuum, 58 (2), 496-501.

24. Sledevskis, E., Gerbreders, V., Teteris, J., \& Bulanovs, A. (2007). Photoinduced processes in $\mathrm{Sb}_{20} \mathrm{Se}_{80}$ thin films. Latv. J. Phys. Tec. Sci., 44 (3), 51-59. 


\section{Sb-Se DIVSLĀN̦U MIKROSTRUKTŪRU ELEKTROVADĪTSPĒJA}

O. Šimane, V. Gerbreders, Ē. Sledevskis, A. Bulanovs

\section{Kopsavilkums}

Fāzu pārejas no amorfā stāvokḷa kristāliskajā stāvoklī parasti tiek pētìtas lielos HSP apjomos pie relatīvi nelielām temperatūras izmaiņām. Tiek pētîtas arī fãzu pārejas, kas noris īsā laikā mazos apjomos, struktūrīpatnības. Pēdējie pētījumos iegūtie dati par fãzu pārejām HSP norāda uz to, ka zibatmiṇu nomaina fāzu inversā atmiņa (phase change RAM, PCRAM). Par darba materiālu PCRAM izmantojām arī Sb-Se sastāvus, tādējādi to izpēte rada noteiktu interesi. Šis darbs ir veltīts procesu, kas noris $\mathrm{Sb}-\mathrm{Se}$ plānajās kārtināas robežvirsmas mikrotilpumos termo un foto iedarbības rezultātā: difūzijai un fāzu pārejai. Tika noteikts, ka mikrostruktūrai, pārejot no nesakārtota stāvokḷa sakārtotā stāvoklī, elektrovadītspēja var palielināties 3 reizes.

27.01.2011. 